\title{
Vegetation Formation in Estuarine Tidal Flats: Influences of Basin Scale and River-Crossing Structures of the Eight Rivers of Ise Bay in Mie and Aichi Prefectures, Japan
}

\author{
Korehisa Kaneko $^{1 *}$, Seiich Nohara ${ }^{2}$ \\ ${ }^{1}$ Ecosystem Conservation Society-Japan, Tokyo, Japan \\ ${ }^{2}$ Center for Environmental Biology and Ecosystem Studies, National Institute for Environmental Studies, Ibaraki, \\ Japan \\ Email: ${ }^{* k}$ kaneko@hotmail.com
}

Received 21 September 2014; revised 21 October 2014; accepted 3 November 2014

Copyright $(\subset 2014$ by authors and Scientific Research Publishing Inc.

This work is licensed under the Creative Commons Attribution International License (CC BY). http://creativecommons.org/licenses/by/4.0/

(c) (i) Open Access

\section{Abstract}

In this study, we examined the influences of the differences in basin scale and river-crossing structures of 8 rivers of Ise Bay in Mie and Aichi Prefectures, Japan on the vegetation in the estuarine tidal flats of these rivers. The dominant plant communities of the estuarine tidal flats formed from rivers of large-scale river basins (exceeding $300 \mathrm{~km}^{2}$ ) were determined. In the Miya River, the dominant plant community was the Suaeda maritima and Artemisia fukudo community. In the Kushida River, the dominant plant community was composed of Phacelurus latifolius, Artemisia fukudo, Phragmites australis, and bamboo. In the Kumozu River, the dominant community was composed of the coastal plants Calystegia soldanella, Lathyrus japonicus, and Carex pumila and the exotic plant of Lolium multiflorum. The plant community of Suzuka River was dominated by the exotic plant of Eragrostis curvula. Among the estuarine tidal flats influenced by a small-scale river basin ( $50 \mathrm{~km}^{2}$ or less), the plant community of Shinbori River (Fukue tidal flat) was dominated by Suaeda maritima, and the plant communities of the Shio and Harai Rivers were dominated by Phragmites australis. The plant community of Tanaka River was dominated by Phragmites australis and coastal plants. Regarding the relationship between the vegetation and the river environment for each study site, we hypothesised that in a large basin area with few structures crossing the river, the river water catchment in the estuary after heavy rains caused large areas of disturbance and formed bare land, providing suitable habitat for an annual salt marsh plant community. In contrast, in cases with many structures crossing the river, a stable channel, an excavated riverbed and the suppression of runoff and the resulting disturbance of the estuary, flooding did

\footnotetext{
"Corresponding author.
} 
not occur during high tide. Moreover, we hypothesised that in a small basin with many structures crossing the river, disturbance to the estuary was not likely, and the perennial salt marsh plant community of Phragmites australis would be widely distributed, except for a river type such as the Shinbori River, in which tide and river flow were managed by a final closure.

\title{
Keywords
}

\author{
Annual Salt Marsh Plant, Perennial Salt Marsh Plant, River-Crossing Structure, Water Level, River \\ Basin
}

\section{Introduction}

Ise Bay is a wide bay that is located in the coastal area between Mie Prefecture and Aichi Prefecture, Japan. Recently, coastal conservation facilities for national land conservation have been developed, but the area occupied by tidal flats is shrinking. In 2007, the Ise Bay regeneration action plan was formulated, which included the restoration of various ecosystems [1]. In many estuarine tidal flats in Ise Bay, different plant communities are present, as described in the Red Data Book of Japan [2]-[4]. The formation of vegetation in estuarine tidal flats is influenced by the ground level [5], the difference between tidal level and surface sediments [6] [7], the scale and frequency of disturbance due to differences in basin areas and annual precipitation [8] [9], and the responses of a dynamic ecosystem to repeated destruction and restoration [10]. In particular, salt marsh plant communities are exposed to the impact of sediment dynamics and the physical environment [11]-[14]. Although we have suggested that the vegetation established in estuarine tidal flat is greatly influenced by the presence of river-crossing structures such as dams and weir-head works in addition to the basin scale, no detailed study has examined the effects of these important factors on estuarine tidal flat vegetation.

In this study, we examined the influences of river-crossing structures and the basin scale on the formation of vegetation in estuarine tidal flats, and we investigated the relationships between the vegetation of estuarine tidal flats and the river environment (i.e., basin area, the crossing structures located in the basin, and changes in water level) in Ise Bay, which is located in Mie and Aichi Prefectures in Japan.

\section{Study Sites and Methods}

\subsection{Environmental Classification of Ise Bay}

The climate of Ise Bay is Pacific Ocean side climate which is summer pluvial high humidity and winter little rain aridity. The air temperature is southern high pressure and northern low pressure, and the highland is lower, the lowland is higher, diurnal range and year range is larger toward the inland.

In the environmental classification of coastal land, foreshore tidal flats characterise Ise Bay, which is located in Aichi and Mie Prefectures. The total area of foreshore tidal flats is 1826 ha, largely confined to the Aichi Prefecture side of the bay. The coastal lands were divided into 3 types (natural coast, sunken rocks/cliffs, and artificial shore protection), and the distribution and area of each coastal type are shown in Figure 1.

The shoreline distances of each coastal type in Ise Bay were $111.6 \mathrm{~km}$ of natural coast, $48.6 \mathrm{~km}$ of sunken rocks/cliffs, and $340.9 \mathrm{~km}$ of artificial shore protection, and artificial shore protection covered approximately $70.0 \%$ of the coastline. Artificial shore protection in Aichi Prefecture accounted for $80.0 \%$ or more of the coastline, and natural coast and artificial shore protection in Mie Prefecture were $52.9 \mathrm{~km}$ and $67.2 \mathrm{~km}$, respectively, with no significant difference between these values (Table 1).

\subsection{Study Sites}

The study sites were 8 rivers (Miya, Kushida, Kumozu, Suzuka, Harai, Tanaka, Shio, and Shinbori) and the vegetation in the estuarine tidal flats of Ise Bay. The scale of the basin of each river was divided into 2 sizes: small and large. We defined a large-scale river basin as one that exceeded $300 \mathrm{~km}^{2}$. In this study, the large-scale river basins were the Miya River, with a basin of $920 \mathrm{~km}^{2}$ (total length = $91 \mathrm{~km}$ ); the Kushida River, with a ba- 


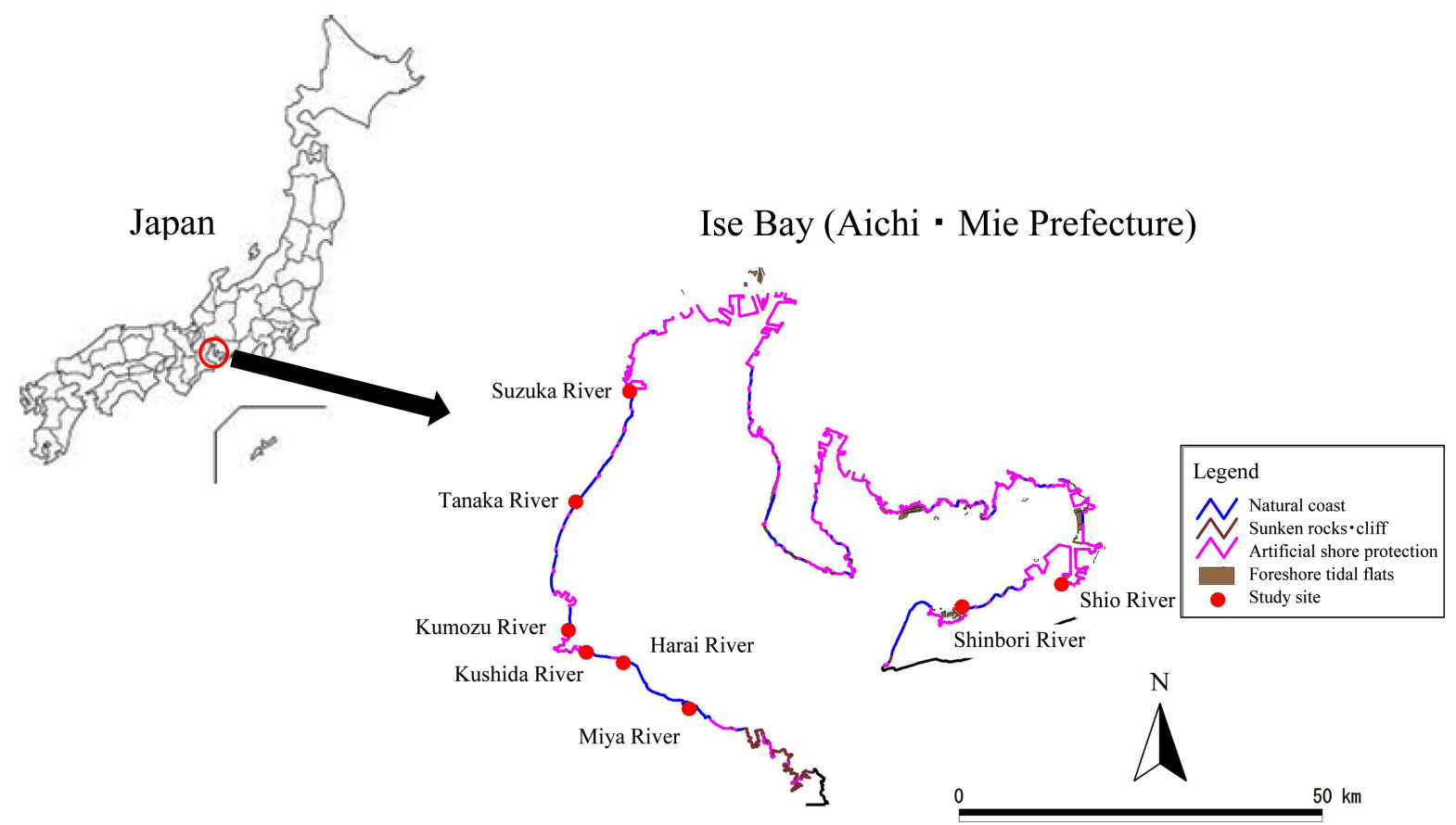

Figure 1. Study site.

Table 1. The distance of each coast type in Ise Bay (km).

\begin{tabular}{lccc}
\hline Coastal type & Aichi Prefecture $(\mathrm{km})$ & Mie Prefecture $(\mathrm{km})$ & Total \\
\hline Natural coast & $58.7(17 \%)$ & $52.9(33 \%)$ & $111.6(22 \%)$ \\
Sunken rocks cliff & $8.8(3 \%)$ & $39.8(25 \%)$ & $48.6(10 \%)$ \\
Artificial shore protection & $273.7(80 \%)$ & $67.2(42 \%)$ & $340.9(68 \%)$ \\
\hline Total & 341.2 & 159.9 & 501.1 \\
\hline
\end{tabular}

Note: ( ) indicates the rate of the distance (\%).

sin of $461 \mathrm{~km}^{2}$ (total length = $85 \mathrm{~km}$ ); the Kumozu River, with a basin of $550 \mathrm{~km}^{2}$ (total length = $55 \mathrm{~km}$ ); and the Suzuka River, with a basin of $323 \mathrm{~km}^{2}$ (total length $=38 \mathrm{~km}$ ). We defined a small-scale river basin as one that was $50 \mathrm{~km}^{2}$ or less. The small-scale river basins were the Harai River, with a basin of $15.2 \mathrm{~km}^{2}$ (total length = $10 \mathrm{~km}$ ); the Tanaka River, with a basin of $8.5 \mathrm{~km}^{2}$ (total length $=4.9 \mathrm{~km}$ ); the Shio River, with a basin of 37.3 $\mathrm{km}^{2}$ (total length $=8.9 \mathrm{~km}$ ); and the Shinbori River, with a basin of $6.3 \mathrm{~km}^{2}$ (total length $=2.2 \mathrm{~km}$ ) (Table 2). Each study site was a sensitive area approximately $1.0 \mathrm{~km}$ upstream from the river mouth, where an estuarine vegetation was formed by the mixing of river flow and tidal flow.

\subsection{Investigation Methods}

We conducted vegetation survey during July of 2008 and 2010. The vegetation map was created based on the plant communities observed in aerial photographs; local confirmation of the plant community was conducted in cases where discrimination based on aerial photographs was difficult. We surveyed the study site to map the distribution of plant communities $(1: 2,500)$. Vegetation data were used to develop a physiognomic vegetation map using GIS (ArcView 3.1, Esri Japan Corporation, Tokyo, Japan). The river environment was investigated for basin area, water level, and river-crossing structures in the basin.

The data on the Suzuka River, Kushida River, Kumozu River and Miya River were collected from the disaster-related information of the Land, Infrastructure and Transportation Ministry [15]. The daily water levels for the Tanaka River, Shio River, Shinbori River and Harai River were measured by the Rivers Divisions of Mie 
Table 2. The type of river environment in each study site.

\begin{tabular}{|c|c|c|c|c|}
\hline Basin scale & Rivers & Total length $(\mathrm{km})$ & Basin area $\left(\mathrm{km}^{2}\right)$ & Annual precipitation (mm) \\
\hline \multirow{4}{*}{ 䜧 } & Miya & 91 & 920 & $\begin{array}{l}\text { Mountainous area: } 2500 \text { - } 3000 \mathrm{~mm} \\
\text { Plains area: approximately } 2000 \text { - } 2500 \mathrm{~mm}\end{array}$ \\
\hline & Kushida & 85 & 461 & $\begin{array}{l}\text { Mountainous area: approximately } 2500 \mathrm{~mm} \\
\text { Plains area: } 1600-2200 \mathrm{~mm}\end{array}$ \\
\hline & Kumozu & 55 & 550 & $\begin{array}{l}\text { Mountainous area: approximately } 2200 \mathrm{~mm} \\
\text { Plains area: } 1600 \text { - } 1800 \mathrm{~mm}\end{array}$ \\
\hline & Suzuka & 38 & 323 & $\begin{array}{l}\text { Mountainous area: approximately } 2200 \mathrm{~mm} \\
\text { Plains area: approximately } 1800-2000 \mathrm{~mm}\end{array}$ \\
\hline \multirow{4}{*}{$\begin{array}{l}\overline{\widetilde{T}} \\
\text { जี }\end{array}$} & Shio & 8.9 & 37.3 & \\
\hline & Harai & 10 & 15.2 & Approximately: 1600 - $2200 \mathrm{~mm}$ \\
\hline & Tanaka & 4.9 & 8.5 & Approximately: 1700 - $2300 \mathrm{~mm}$ \\
\hline & Shinbori & 2.2 & 6.3 & \\
\hline
\end{tabular}

Note: annual precipitation of Tanaka River is the average annual precipitation (1889-2010) of Tushi City.

Prefecture, Aichi Prefecture and Tawara City in Aichi Prefecture. For the Shinbori River, there were no data before 2011 because the water level measurements began in 2011. The tidal level data of the Fukue tidal flat, including the Shinbori River estuary, were from the tidal data of the Rivers Division in Aichi Prefecture. We were not included in the survey item the flow volume because data were not available for all rivers. The information on river-crossing structures for the Suzuka River, Kushida River, Harai River, Kumozu River, and Miya River was obtained from basin jurisdiction maps made by the Mie Office of Rivers and National Highways and the Chubu Regional Bureau in Land, Infrastructure and Transport. Information on the river-crossing structures of the Shinbori River and Shio River was obtained from basin jurisdiction maps made by the Rivers Division of Aichi Prefecture. The Tanaka River information was obtained from a survey by the River Sediment Control Division in Mie Prefecture.

\section{Analytical Methods}

\subsection{The Characteristics of Each River}

We investigated the basin areas, the plant community types, the water level fluctuation periods (i.e., the number of germination, growth and overwintering periods during which the water level exceeded $0.5 \mathrm{~m}$ ), and the number of maintained river-crossing structures (i.e., dams, weir/head works, hydraulic drops). The fluctuation of water levels affected the means and standard deviations of the germination and growth periods (Mar-May), the growth period (Jun-Oct) and the overwintering period (Nov-Feb) of plants based on the above data. The change in water level was relatively high, at $0.5-1.0 \mathrm{~m}$, and we characterised the disturbance occurrence as high when the change in the water level exceeded $0.5 \mathrm{~m}$.

\subsection{Classification of Vegetation Types}

Vegetation types were divided into salt marsh plants (annual and perennial plants), exotic plants, and upland plants. Salt marsh plants were defined as plants that grow in the marshes and wetlands in the estuaries, lagoons and coastal areas. Upland plants were defined as plants that grow in areas with a strong artificial influence such as landfills, primarily [16], and a with low soil water content [17]. Exotic plants were defined as plants that were transported artificially from overseas and that had arrived mainly since the Edo period [18].

\subsection{Multivariate Analysis (Principal Component Analysis)}

The data were analysed using principal component analysis to reveal the difference in plant community types in each study site. Principal component analysis is a statistical method for creating a new comprehensive evaluation using these data, when there is data obtained by measuring the evaluation items. This is a method using when we would like to evaluate using new comprehensive evaluation and classify at each other be similar the people and 
things. The analyses were performed using R2.4.1 Vegan1.8-4 software (http://www.r-project.org,2007.1).

\section{Results}

\subsection{Vegetation in the Study Sites}

The dominant plant communities of the estuarine tidal flats were variable in the large-scale river basins. In the Miya River, the Suaeda maritima and Artemisia fukudo community occupied a relatively wide range. In the Kushida River, the Phacelurus latifolius community was the most widely distributed, with various species such as Artemisia fukudo, Phragmites australis and bamboo also found. In the Kumozu River, the coastal plant community of Calystegia soldanella, Lathyrus japonicus, and Carex pumila and the exotic species of Lolium multiflorum were the most widely distributed. Other plants, such as Suaeda maritima, Carex scabrifolia, Zoysia sinica, Atriplex subcordata, and Phragmites australis, among others, were distributed locally. In the Suzuka River, the exotic plant community of Eragrostis curvula was the most widely distributed, and Phragmites australis, Imperata cylindrica, Carex kobomugi, Solidago canadensis, and woody plants were distributed locally. Among the estuarine tidal flats in the small-scale river basins, in the Shinbori River (Fukue tidal flat), the Suaeda maritima community was the most widely distributed, and the Artemisia fukudo community was distributed locally. In the Shio River, the Phragmites australis community occupied the widest range, and Triglochin maritima, Carex scabrifolia, and Zoysia sinica, among other species, were distributed locally. In addition, bamboo and woody plants, which originally were not found in the estuarine tidal flats, were found. In the Harai River, the Phragmites australis community was distributed most widely, and Phacelurus latifolius and Miscanthus sinensis were also found. In the Tanaka River, the Phragmites australis community and the coastal plant community occupied the widest ranges, and Suaeda maritima, Carex scabrifolia, Zoysia sinica, and other species were distributed locally (Figure 2, Table 3).

\subsection{Dominant Species of the Community and Degree of Dominance in Each Study Site}

In the estuarine tidal flats of large-scale river basins, community analysis revealed that for the Miya River, the Suaeda maritima and Artemisia fukudo community, made up of annual salt marsh plants (in the area flooded during high tide), had the highest coverage at $41.0 \%$, followed by Phragmites australis at $35.4 \%$, Solidago canadensis at $10.9 \%$, Imperata cylindrica at $3.1 \%$ and woody plants at $3.0 \%$. In the Kushida River, Phacelurus latifolius was dominant with $30.7 \%$ coverage, followed by bamboo at $16.6 \%$; Artemisia fukudo at $13.9 \%$, Phragmites australis at $12.4 \%$ and Solidago canadensis at $7.0 \%$. The plant species of the non-flooding type were the highest in the tidal flat. In the Kumozu River, Lolium multiflorum had the highest coverage at $28.0 \%$, followed by Calystegia soldanella at 17.1\%; coastal plants at 15.8\%, Lathyrus japonicas at $12.5 \%$ and Carex pumila at $8.3 \%$. Thus, coastal plants occupied a high percentage of the total. In the Suzuka River, Eragrostis curvula, which an exotic plant, had the highest coverage at $61.8 \%$, followed by Phragmites australis at $8.0 \%$, Imperata cylindrica at $6.1 \%$, Carex kobomug at $5.3 \%$, and woody plants at $5.0 \%$. In the estuarine tidal flats of small-scale river basins, community analysis revealed that for the Shinbori River, Suaeda maritima had the highest coverage at $77.7 \%$, followed by Artemisia fukudo at $13.5 \%$, Zoysia sinica at $2.4 \%$, Carex scabrifolia at $1.7 \%$, Limonium tetragonum at $1.6 \%$ and Suaeda glauca at $1.5 \%$. Thus, annual salt marsh plants had the highest coverage. In the Shio River, Phragmites australis had the highest coverage at $87.1 \%$, followed by Phacelurus latifolius at $6.5 \%$; woody plants at $2.3 \%$, bamboo at $1.7 \%$ and Triglochin maritima at $0.9 \%$. In the Harai River, Phragmites australis had the highest coverage at $65.0 \%$, followed by Miscanthus sinensis at $18.4 \%$, Phacelurus latifolius at $11.0 \%$, Eragrostis curvula at $2.2 \%$ and Pueraria lobata at $2.2 \%$. In the Shio and Harai Rivers, the coverage of Phragmites australis, which is a perennial salt marsh plant was high. In the Tanaka River, Phragmites australis and coastal plants had the highest coverage at $47.0 \%$ and $41.9 \%$, respectively. Other species included Miscanthus sinensis at 1.9\%, Suaeda maritima at $1.9 \%$ and other herbaceous plants at $1.6 \%$. Thus, the coverage of perennial salt marsh plants (in the area flooded during high tide) and coastal plants was high (Table 4).

\subsection{Vegetation Types}

An analysis of the vegetation types in the estuarine tidal flats of the large-scale river basins revealed that in the Miya River, the plant communities that occupied the greatest area were the annual salt marsh plant community, which occupied $36.1 \%$ of the area, and the perennial salt marsh plant community (in the area flooded during 
(1)Miya River

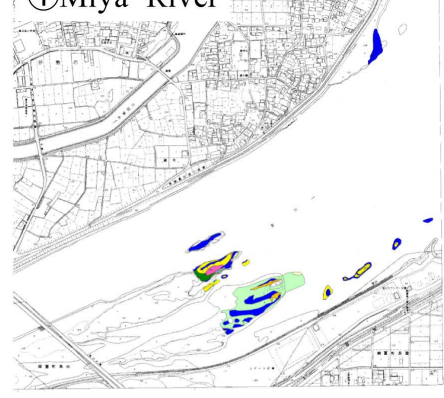

\section{(2)Kushida River}
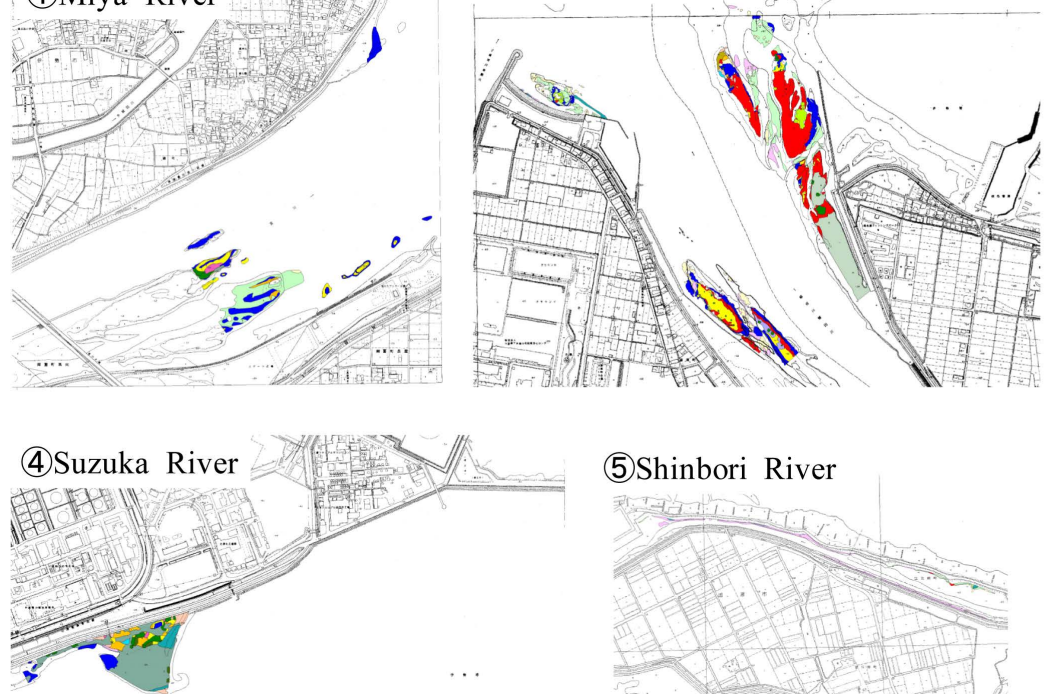

कामा

\section{(7)Harai River}

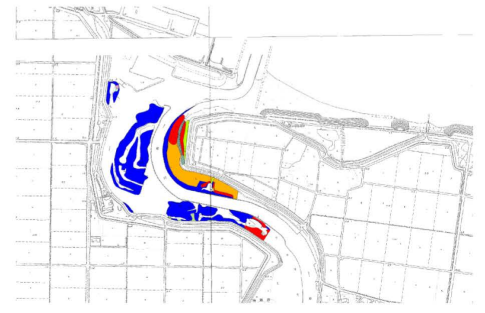

(5)Shinbori River

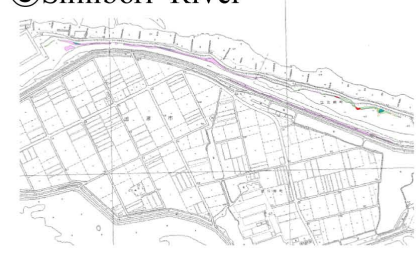

(8)Tanaka River

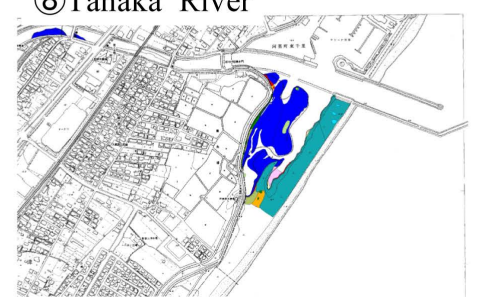

(3)Kumozu River
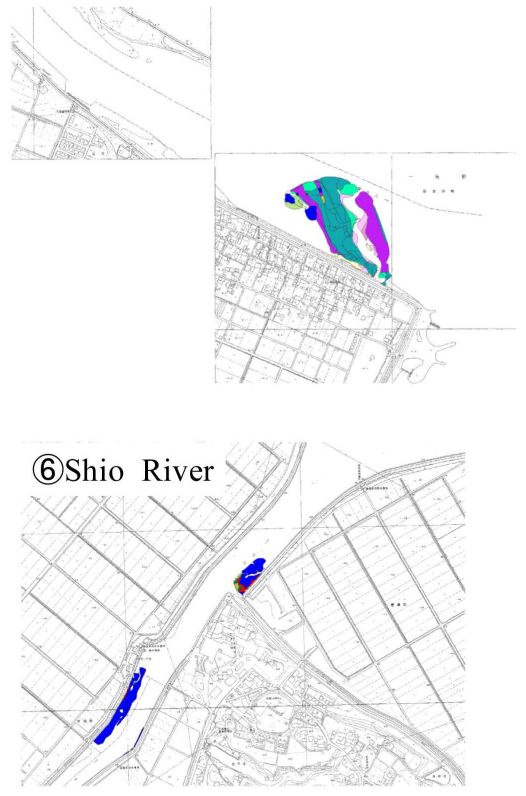

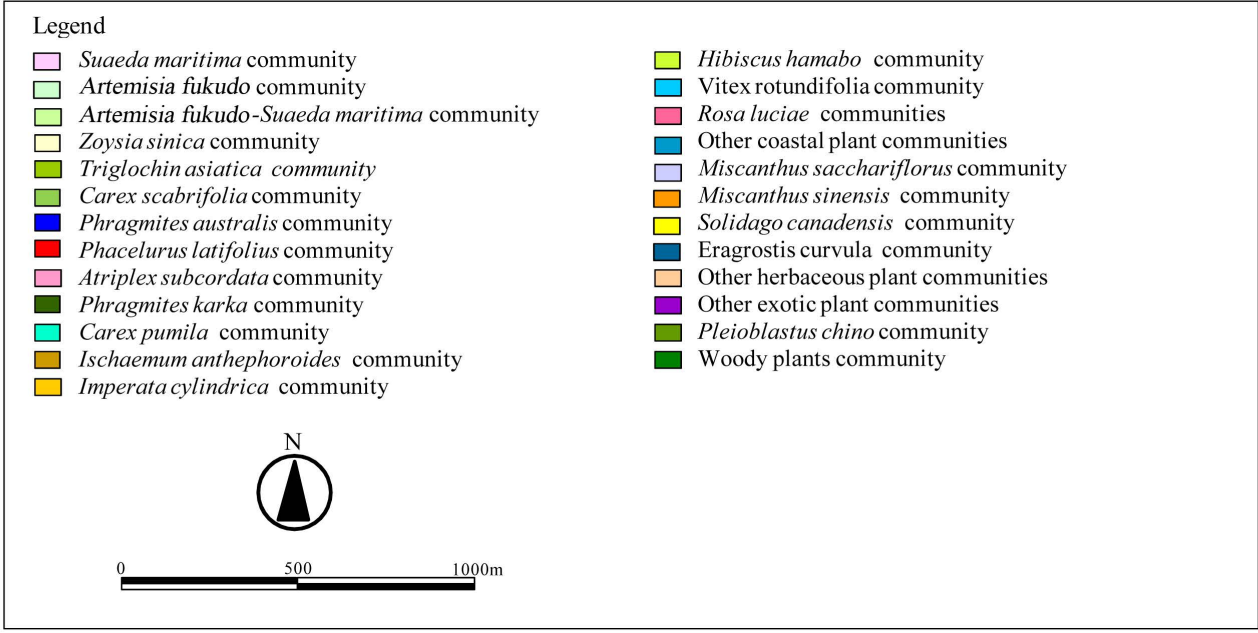

Figure 2. Vegetation map of each study site.

high tide), which occupied $36.1 \%$ of the area. In the Kushida River, the perennial salt marsh plants (in the area not flooded during high tide) had the widest distribution with the addition of bamboo, the upland (native and exotic) plant community and the coastal plant community, and more than $60.0 \%$ of study site area was not flooded during high tide. In the Kumozu River, the coastal plant community occupied over 50.0\% of the area, the upland 
Table 3. The areas of the plant communities found in the study sites $\left(\mathrm{m}^{2}\right)$.

\begin{tabular}{|c|c|c|c|c|c|c|c|c|}
\hline \multirow{3}{*}{ Communities } & \multicolumn{8}{|c|}{ Basin area } \\
\hline & \multicolumn{4}{|c|}{ Large scale } & \multicolumn{4}{|c|}{ Small scale } \\
\hline & Miya & Kushida & Kumozu & Suzuka & Shinbori & Shio & Harai & Tanaka \\
\hline \multicolumn{9}{|l|}{ Annual salt marsh plant community } \\
\hline Suaeda maritima & 31 & 4154 & 2766 & 297 & 4660 & & & 948 \\
\hline Artemisia fukudo & 92 & 13,049 & & & 808 & & 172 & \\
\hline Suaeda maritima-Artemisia fukudo & 11,421 & & & & & & & \\
\hline Suaeda glauca & & & & & 91 & & & \\
\hline Atriplex subcordata & & & 555 & & & & 81 & \\
\hline \multicolumn{9}{|l|}{ Biennial salt marsh plant community } \\
\hline Limonium tetragonum & & & & & 94 & & & \\
\hline \multicolumn{9}{|c|}{ Perennial salt marsh plant community (flooding type at tidal flat) } \\
\hline Carex scabrifolia & & 258 & 1035 & & 99 & 78 & 202 & 565 \\
\hline Zoysia sinica & 176 & 5979 & 1222 & & 142 & 28 & & 325 \\
\hline Sonchus brachyotus & & & & & & & & 95 \\
\hline Triglochin maritimum & & & & & 17 & 97 & & \\
\hline Phragmites australis & 9871 & 11,640 & 1716 & 2902 & & 8968 & 26,239 & 24,133 \\
\hline Phragmites karka & & & & 678 & & & & \\
\hline \multicolumn{9}{|c|}{ Perennial salt marsh plant community (non-flooding type at tidal flat) } \\
\hline Phacelurus latifolius & & 28,778 & & & 87 & 673 & 4432 & 306 \\
\hline \multicolumn{9}{|l|}{ Coastal plant community } \\
\hline Imperata cylindrica & 854 & 518 & & 2210 & & & & \\
\hline Calystegia soldanella & & & 6988 & 319 & & & & \\
\hline Carex pumila & & & 3386 & & & & & \\
\hline Carex kobomugi & & & & 1929 & & & & \\
\hline Lathyrus japonicus & & & 5119 & & & & & \\
\hline Ischaemum anthephoroides & & 579 & & & & & & \\
\hline Angelica japonica & & & & & & 15 & & \\
\hline Vitex rotundifolia & 31 & 261 & & 223 & & & & 262 \\
\hline Hibiscus hamabo & & 1894 & & & & & 877 & 32 \\
\hline Coastal plants & & 1342 & 6457 & & & & & 21,521 \\
\hline \multicolumn{9}{|l|}{ Land plant (native) community } \\
\hline Rosa multiflora & 749 & & & 229 & & & & \\
\hline Miscanthus sacchariflorus & & 1,144 & & 114 & & & & 50 \\
\hline Miscanthus sinensis & & & & 176 & & 34 & 7419 & 968 \\
\hline Pueraria lobata & & & & & & & & 49 \\
\hline Other herbaceous plants & 24 & 526 & & & & & & 826 \\
\hline \multicolumn{9}{|l|}{ Land plant (exotic) community } \\
\hline Solidago canadensis-Miscanthus sinensis & 529 & & & & & & & \\
\hline Solidago canadensis & 3034 & 6591 & 49 & 1213 & & & 29 & \\
\hline Eragrostis curvula & 211 & & & 22,437 & & & 900 & \\
\hline Sorghum halepense & & & & 508 & & & & \\
\hline Lolium multiflorum & & & 11,456 & 342 & & & & \\
\hline Xanthium occidentale & & & & 904 & & & & \\
\hline \multicolumn{9}{|l|}{ Woody plant community } \\
\hline Bamboo & & 15,527 & 128 & & & 174 & & 525 \\
\hline Woody plants & 830 & 1428 & & 1825 & & 235 & & 769 \\
\hline Total & 27,853 & 93,668 & 40,877 & 36,306 & 5998 & 10,302 & 40,351 & 51,374 \\
\hline
\end{tabular}


Table 4. Order of plant community dominance in the each river.

\begin{tabular}{|c|c|c|c|c|c|c|c|c|}
\hline \multirow{2}{*}{ No. } & \multicolumn{4}{|c|}{ Large-scale basin } & \multicolumn{4}{|c|}{ Small-scale basin } \\
\hline & Miya & Kushida & Kumozu & Suzuka & Shinbori & Shio & Harai & Tanaka \\
\hline 1 & Su-Ar (41.1) & Phace (30.7) & Lo (28.0) & $\operatorname{Er}(61.8)$ & Su (77.7) & Phra (87.1) & Phra (65.0) & Phra (47.0) \\
\hline 2 & Phra (35.4) & Ва (16.6) & Caly (17.1) & Phra (8.0) & $\operatorname{Ar}(13.5)$ & Phace (6.5) & Mi (18.4) & Co (41.9) \\
\hline 3 & So (10.9) & $\operatorname{Ar}(13.9)$ & Co (15.8) & $\operatorname{Im}(6.1)$ & Zo (2.4) & Wo (2.3) & Phace (11.0) & $\operatorname{Mi}(1.9)$ \\
\hline 4 & $\operatorname{Im}(3.1)$ & Phra (12.4) & $\mathrm{La}(12.5)$ & Ca-ko (5.3) & Ca (1.7) & $\mathrm{Ba}(1.7)$ & $\operatorname{Er}(2.2)$ & Su (1.9) \\
\hline 5 & Wo (3.0) & So (7.0) & Ca-pu (8.3) & Wo (5.0) & $\mathrm{Li}(1.6)$ & Tri (0.9) & $\mathrm{Hi}(2.2)$ & Her (1.6) \\
\hline
\end{tabular}

Note: ( ) indicates the dominance degree of plant community. Su: Suaeda maritima community; Su-Ar: Suaeda maritima-Artemisia fukudo community; Phra: Phragmites australis community; Phace: Phacelurus latifolius community; So: Solidago canadensis community; Hi: Hibiscus hamabo community; Tri: Triglochin maritimum community; Ba: Bamboo; Zo: Zoysia sinica community; Mi: Miscanthus sinensis community; Co: Others coastal plants community; Ca: Carex pumila community; Er: Eragrostis curvula community; Im: Imperata cylindrica community; Ex: Exotic plants community; Li: Limonium tetragonum community; Her: Herbaceous community; Lo: Lolium multiflorum community.

(exotic) plant community occupied nearly 30.0\%, and the annual salt marsh plant community and perennial salt marsh plant communities were distributed locally. In the Suzuka River, the upland (exotic) plant community occupied $70.0 \%$ or more of the area. In the estuarine tidal flats of small-scale river basins, vegetation analysis revealed that for the Shinbori River, the annual salt marsh plant community occupied $92.7 \%$ of the area. In the Shio and Harai Rivers, the perennial salt marsh plant community in the area flooded during high tide was the most widely distributed, whereas the perennial salt marsh plant community in the area not flooded during high tide was distributed locally. In the Tanaka River, the perennial salt marsh plant community and coastal plant communities occupied the largest areas (Figure 3).

We used principal component analysis to analyse the difference in plant community types in each study site. PCA revealed that these community types could be divided into several groups: the annual salt marsh plant communities of the Shinbori River; the annual salt marsh plant communities and perennial salt marsh plant communities of the Miya River; various types of annual salt marsh plant communities, perennial salt marsh plant communities in the area flooded during high tide, perennial salt marsh plant communities in the area not flooded during high tide and woody plants of the Kushida River; the perennial salt marsh plant community in the area flooded during high tide of the Shio and Harai Rivers; the perennial salt marsh plant community in the area flooded during high tide and the coastal plant community of the Tanaka River; the coastal plant community and upland (exotic) plant community of the Kumozu River; and the upland (exotic) plant community of the Suzuka River (Figure 4).

\subsection{Water Level Change}

We investigated the average water level and the water level change (standard deviation) during the germination period (March-May), the growth period (Jun-Oct) and the overwintering period (Nov-Feb) based on the water level data from the observation point at each study site. With regard to large-scale river basins, in the Miya River, the average water level was high during germination and growth periods, with a water level change of approximately $0.5 \mathrm{~m}$ and periods exceeding $0.5 \mathrm{~m}$ observed frequently. In the Kushida River, the average water level was high during the growth period. In particular, the water level change during the growth periods in 2010 and 2011 was approximately $0.6 \mathrm{~m}$. In the Kumozu River, the average water levels during the germination and growth periods were high, whereas no water level change in the Suzuka River was observed. For small-scale river basins, in the Tanaka River, the average water level was the highest during the germination period and was lower during the growth period and overwintering periods. The water level change was occasionally greater than $0.5 \mathrm{~m}$ during the growth period of 2008, overwintering period of 2011 and germination period of 2012. In the Harai River, although the average water level was high during the growth period, the water level change was less than $0.5 \mathrm{~m}$. In the Shinbori River and the Shio River, the water level changes were less than $0.2 \mathrm{~m}$ (Figure 5). Therefore, the water level changes in small-scale river basins were smaller than those observed in large-scale river basins. 
Component ratio of plant community area (\%)

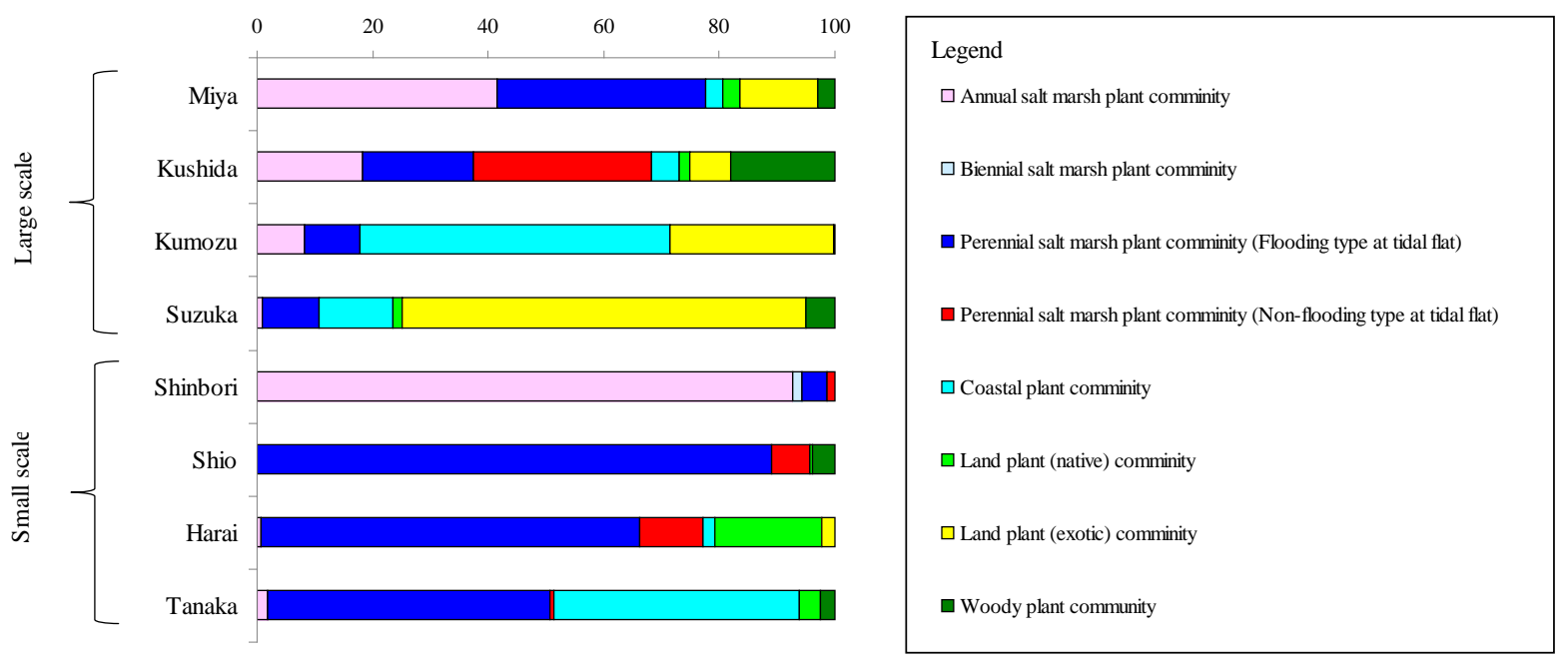

Figure 3. The composition of the plant community types in each study site.

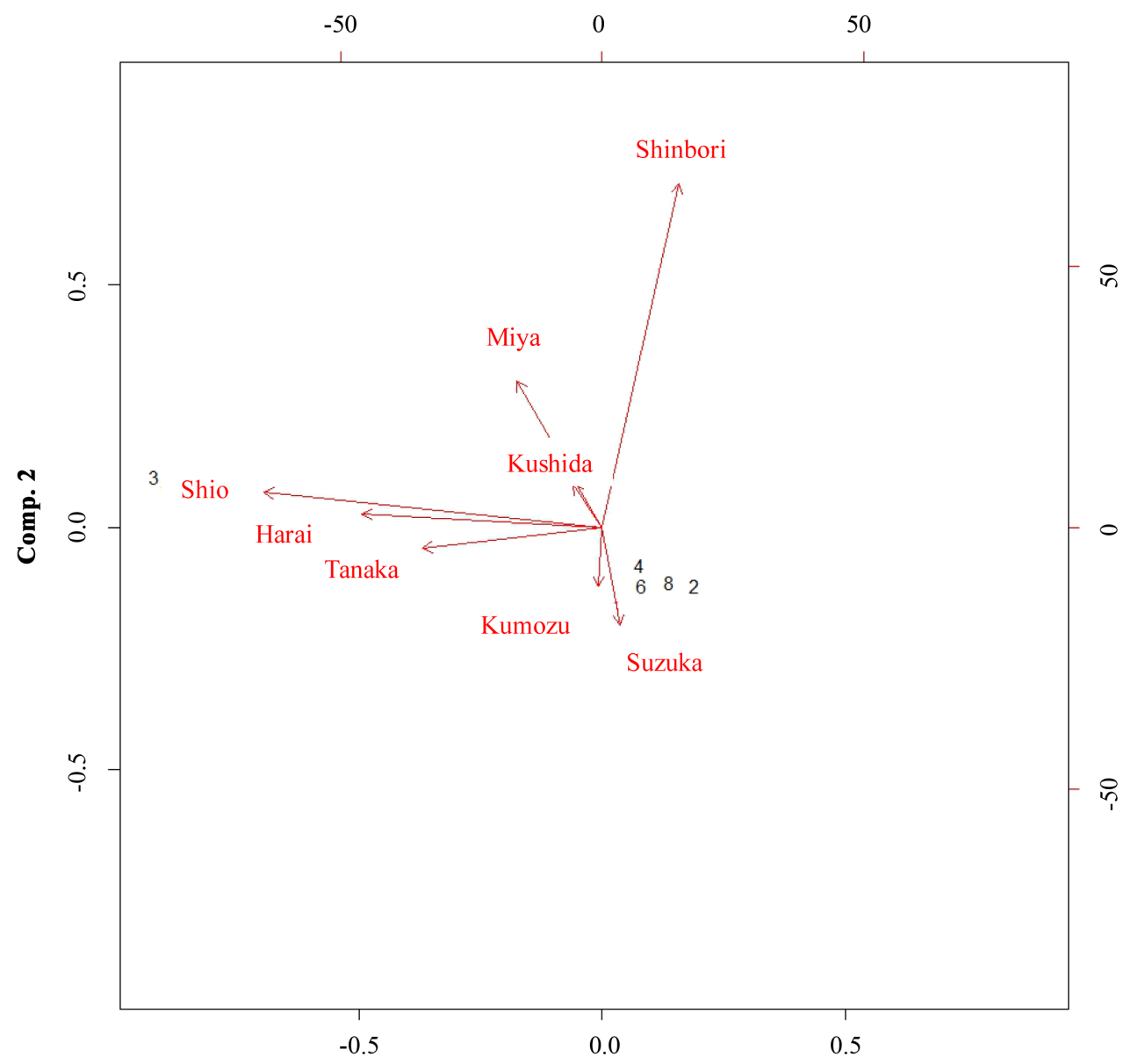

Comp. 1

Eigenvalue (Comp.1 1.558092e+03, Comp.2 1.116959e+03 )

Figure 4. Classification of the vegetation of the study sites determined with principal component analysis. 


\subsection{The Environment of the Study Sites}

We investigated the dominant plant community types, basin areas, and river-crossing structures as environmental factors to evaluate each tidal flat and water level change (frequency with which the water level change was greater than $0.5 \mathrm{~m}$ ). With regard to the water level change of large-scale river basins, the water level in the Miya River changed once during the germination period and 4 times during the growth period. In the Kushida River, the water level changed once during the growth period, and the water level in the Tanaka River changed once during the growth period. In the Suzuka River, the water level change never exceeded $0.5 \mathrm{~m}$. With regard to the river-crossing structures of these rivers, in the Miya River, there were 2 dams, but there was no weir or
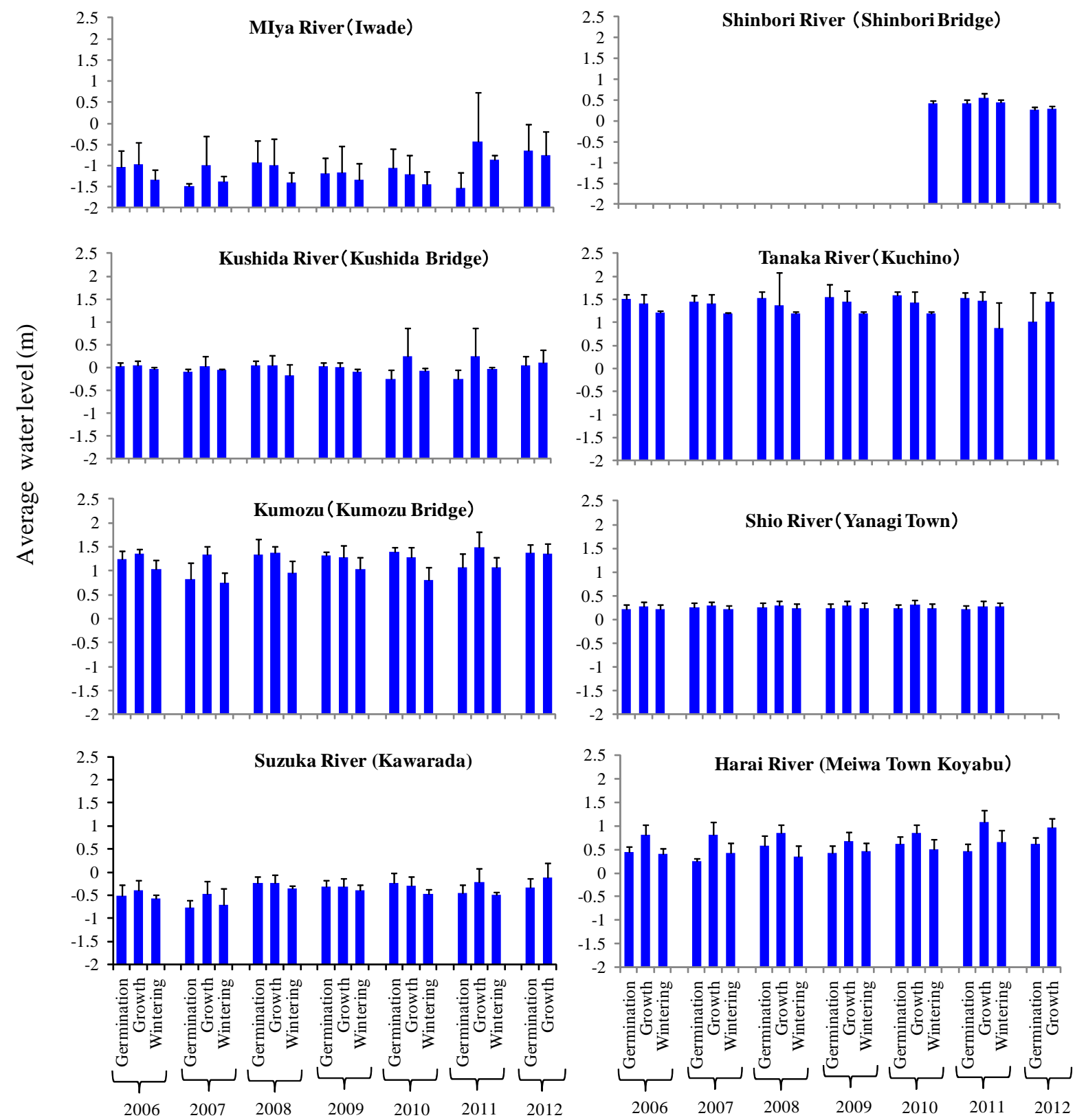

Figure 5. The change in water level at each study site. Vertical bar represents the standard deviation (in the period of change in water level, data for the Harai River were recorded from Jan 2011 to Dec 2012, and for the Shio River, from Jan 2006 to Dec 2011. Germination: germination period (Mar-May); Growth: growth period (Jun-Oct); Wintering: wintering period (Nov-Feb)). 
head works. In the Kushida River, there was a dam, and there were five weirs and head works in the main river and nine in a branch. In the Suzuka River, there was no dam; however, there were 10 weirs and head works in the main river and 5 in a branch. In contrast, with regard to the small-scale river basins, in the Shinbori River, there was a weir near the estuary and 2 hydraulic drops upstream. In the Shio River, there was not dam, but there was a weir and a head works; however, there were 16 hydraulic drops in the main river and 21 drops in a branch. In the Harai River, there was a weir and head works, and in the Tanaka River, there were 6 weirs and head works (Table 5).

\section{Considerations}

The annual salt marsh plant community of Suaeda maritima and Artemisia fukudo occupied over $40.0 \%$ of the estuarine tidal flats of the Miya River, which is a large-scale river basin $\left(920 \mathrm{~km}^{2}\right)$, and occupied over $90.0 \%$ of the estuarine tidal flats of the Shinbori River, which is a small-scale river basin $\left(6.3 \mathrm{~km}^{2}\right)$. In case of the Miya River, the average water level was higher during the germination and growth periods, and the water level change was higher compared with that observed in other rivers at $0.5-1.1 \mathrm{~m}$. In contrast, there was a final closure in the estuarine tidal flat of the Shinbori River, and the water level change was lower compared with that of the other rivers at approximately $0.1 \mathrm{~m}$ (Figure 5). The annual salt marsh plant community of Suaeda maritima and Artemisia fukudo in the Miya River expanded after water volumes and water levels were extremely high. Therefore, annual salt marsh plants, which are pioneer species, were distributed on the bare land that appeared following the flooding disturbance [8]. Moreover, although the upper area of the Miya River had 2 dams, no weir or head works were found (Table 5).

We considered the catchment as a whole progressed from basin to estuary and that the annual salt marsh plant communities were formed by disturbance that occurred in the estuary when rainfall in the upper areas of the catchment was high. In contrast, the basin area of Shinbori River was smaller compared with that of Miya River; in addition, there was a final closure in the estuary. As a result, compared with the tide level during high tide in the Fukue tidal flat, which is located in an estuary of Shinbori River, the water level of the Shinbori River (the observation point was located in upstream of final closure) at high tide during the germination and growth periods was much lower (Figure 6).

\section{Table 5. The type of river environment in each study site.}

\begin{tabular}{|c|c|c|c|c|c|c|c|c|c|c|c|c|c|c|c|}
\hline \multirow{3}{*}{$\begin{array}{l}\text { Basin } \\
\text { scale }\end{array}$} & \multirow{3}{*}{ Rivers } & \multirow{2}{*}{\multicolumn{4}{|c|}{$\begin{array}{l}\text { Dominant plant } \\
\text { community type }\end{array}$}} & \multirow{3}{*}{\multicolumn{2}{|c|}{$\begin{array}{l}\text { Basin area } \\
\left(\mathrm{km}^{2}\right)\end{array}$}} & \multirow{3}{*}{ Dam } & \multicolumn{4}{|c|}{ River-crossing structure } & \multirow{2}{*}{\multicolumn{3}{|c|}{$\begin{array}{l}\text { Water level change } \\
\text { (Jan 2006-Jul 2010) }\end{array}$}} \\
\hline & & & & & & & & & \multicolumn{2}{|c|}{ Wear headworks } & \multicolumn{2}{|c|}{ Hydraulic drop } & & & \\
\hline & & (1) & (2) & (3) & (4) & & & & $\begin{array}{l}\text { Main } \\
\text { river }\end{array}$ & Branch & $\begin{array}{l}\text { Main } \\
\text { river }\end{array}$ & Branch & a & $\mathrm{b}$ & c \\
\hline \multirow{4}{*}{ 范 } & Miya & IV & IV & - & + & II & 920 & 2 & & & & & 1 & 4 & \\
\hline & Kushida & II & II & III & + & III & 461 & 1 & 8 & & & & & 1 & \\
\hline & Kumozu & I & I & - & IV & III & 550 & 1 & 5 & 9 & & 1 & & & \\
\hline & Suzuka & + & I & - & II & $\mathrm{V}$ & 323 & & 10 & 5 & & & & & \\
\hline \multirow{4}{*}{$\begin{array}{l}\text { नี } \\
\text { ตี }\end{array}$} & Shinbori & VI & + & + & - & - & 6.3 & & 1 & & 2 & & & & \\
\hline & Shio & - & VI & I & + & + & 37.3 & & & & 16 & 21 & & & \\
\hline & Tanaka & + & IV & + & IV & I & 8.5 & & 6 & & & & & 1 & \\
\hline & Harai & + & $\mathrm{V}$ & I & I & III & 15.2 & & 1 & & & & & & \\
\hline \multicolumn{11}{|c|}{ Dominant community type } & \multicolumn{5}{|c|}{ Component rate of the area (\%) } \\
\hline \multicolumn{11}{|c|}{ (1) Annual salt marsh plant community } & + & $0 \%-5 \%$ & & & \\
\hline \multicolumn{11}{|c|}{ (2) Perennial salt marsh plant community (flooding type at tidal flat) } & I & $5 \%-10 \%$ & & & \\
\hline \multicolumn{11}{|c|}{$\begin{array}{l}\text { (3) Perennial salt marsh plant community (non-flooding type at tidal } \\
\text { flat) }\end{array}$} & II & $10 \%-20 \%$ & & & \\
\hline \multicolumn{11}{|c|}{ (4) Coastal plant community } & III & $20 \%-40 \%$ & & & \\
\hline \multicolumn{11}{|c|}{ (5) Land exotic plant community } & IV & $40 \%-60 \%$ & & & \\
\hline \multicolumn{11}{|c|}{ Water level change } & $\mathrm{V}$ & $60 \%-80 \%$ & & & \\
\hline \multicolumn{11}{|c|}{ a) Germination period (Mar-May) } & VI & $80 \%-100 \%$ & & & \\
\hline \multicolumn{11}{|c|}{ b) Growth period (Jun-Oct) } & - & No communica & ion & & \\
\hline \multicolumn{16}{|c|}{ c) Wintering period (Nov-Feb) } \\
\hline
\end{tabular}

Note: the number is indicated the number of times in the period that the change of water level was over $0.5 \mathrm{~m}$; in the period of water level, data for the Harai River were recorded only from Jan 2011 to Dec 2012. 
With respect to the growth environment of these species, Suaeda maritima disseminates its seed via the tide [19] and may form soil seed banks [20]. Suaeda maritima occurs at low elevations that are disturbed by flooding at high tide [5], and Suaeda maritima and Limonium tetragonum prefer the fine gravel and pebble gravel substrates that occur below the spring high tide level [7]. In contrast, Artemisia fukudo grows in the mud substrate that is flooded by seawater during high tide in the river tidal areas, and it is a winter annual plant that flowers during the autumn [21]-[23]. Moreover, Artemisia fukudo grows in the coastal wetlands with high soil salinity, and the high soil salinity tolerance of this species includes a salt-tolerant seed germination system and a photosynthetic system [24].

Therefore, we hypothesised that the sediment supply of the Shinbori River was suppressed from upstream by the final closure sluice. However, this structure caused sedimentation and erosion by tidal flow and sea water during high tide below the final closure sluice; therefore, the annual salt marsh plant community, which has high tolerance to salt and disturbance, formed there as a result of factors that were different from those leading to the establishment of the annual salt marsh plant community in the Miya River.

The annual salt marsh plant community and perennial salt marsh plant community in the Kushida River were distributed in a branch and in the estuarine tidal flats and occupied approximately $40.0 \%$ of the entire area. Moreover, Phacelurus latifolius, which is a perennial salt marsh plant (occupying non-flooded areas during high tide), occupied $30.7 \%$ of the area; bamboo occupied $16.6 \%$; and plant communities occupying non-flooded areas during high tide occupied half of the total area. In the Kushida River, the flow of water volume was over 1000 $\mathrm{m}^{3} \cdot \mathrm{s}^{-1}$; the riverbed was eroded; and it was difficult for vegetation to form. Subsequently, with a water level of 1 - $3 \mathrm{~m}$ and a water volume flow of $500-700 \mathrm{~m}^{3} \cdot \mathrm{s}^{-1}$, sand was deposited, and the Suaeda maritima and Artemisia fukudo community formed on the sand [9]. Phacelurus latifolius grows in the sand and silt of the water's edge near the coast [25] and bamboo grows in colonies on the hills near the coast and on the banks of the river [26].

The Kushida River had 8 weirs and head works and a dam in the basin area. The river had several crossing structures in its basin area. We considered that the channel was stable; the evacuation of the riverbed was progressed; and the river became unusually resistant to disturbance, which favoured the Phacelurus latifolius community and bamboo. Therefore, we hypothesised that the disturbance was restricted to a branch and part of an estuary when rapid water level changes occurred as a result of, for example, an open weir gate during a heavy rain.

In the Kumozu River, the coastal plant community (Calystegia soldanella, Lathyrus japonicas, etc.) occupied over $50.0 \%$ of the area, and the exotic plant community (Lolium multiflorum, etc.) occupied $28.2 \%$ of the area. In the Suzuka River, the exotic plant community of Eragrostis curvula occupied approximately $70.0 \%$ of the area, and plant communities occupying areas not flooded during high tide exhibited a wide distribution, whereas annual salt marsh plants communities occupied $10.0 \%$ or less of the area of both rivers (Figure 3 ). With regard to

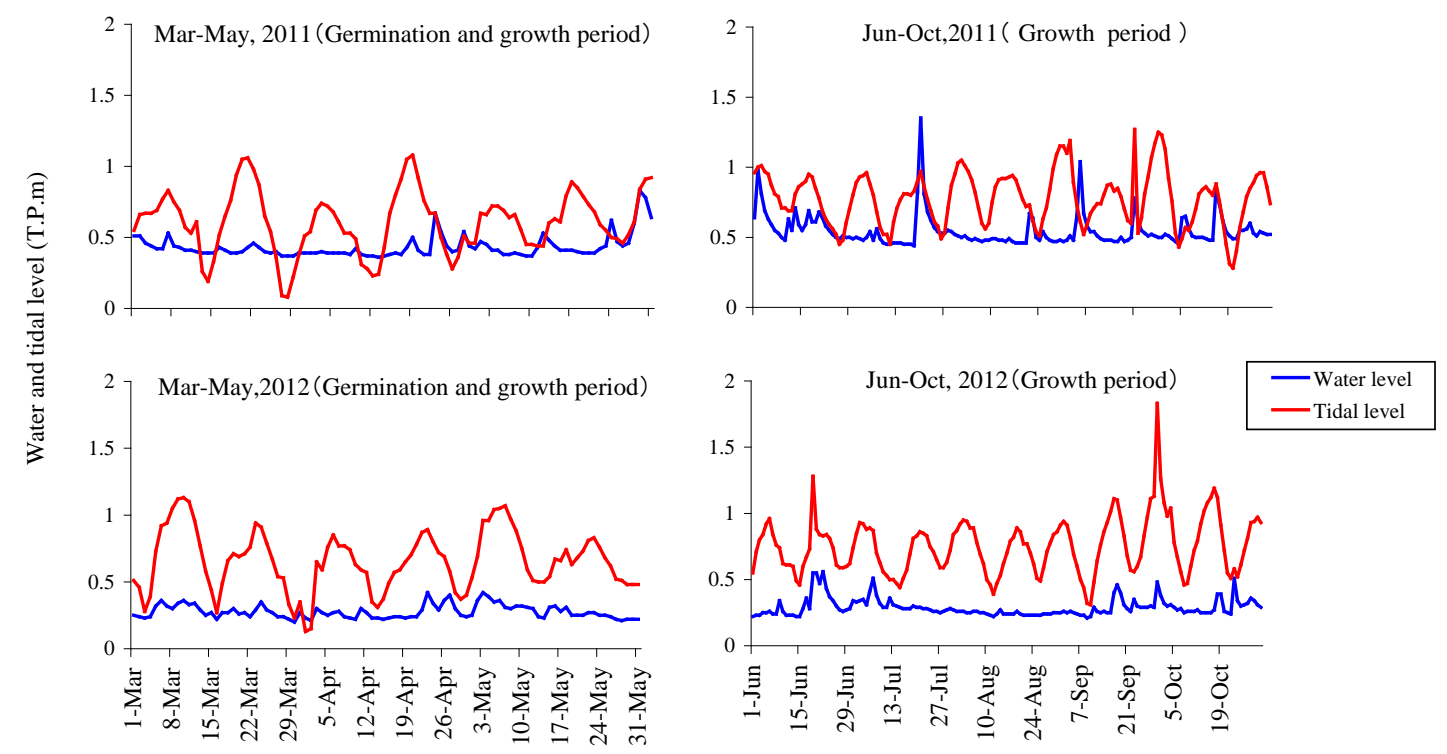

Figure 6. Comparison of water levels in the Shinbori River and tide levels (highest tide) in the Fukue tidal flats. 
the average water level before the vegetation study in both rivers, the water level of Kumozu River was slightly higher during the germination and growth periods, and the Suzuka River water level was largely unchanged. Moreover, the water level change did not exceed the maximum of $0.4 \mathrm{~m}$ in either river, remaining at $0.2-0.3 \mathrm{~m}$ (Figure 5).

[8] reported that Eragrostis curvula in the Suzuka River was found in locations where the sand was deposited largely in the estuarine tidal flats and areas that did not flood during high tide. Eragrostis curvula, which grows in the neighbouring area, germinated, grew and was distributed by water and wind dispersal. [27] reported that vegetation was stabilised when the tidal level was constant. The river-crossing structures on the Kumozu River included a dam and weir and head works at 14 sites, and on the Suzuka River, there were weir and head works at 15 sites, including both the tributaries and the main stream (Table 5). We considered that the water catchment near the estuary was low as a result of the adjustment of the water level and water volume caused by the dam and weir, and as disturbance in the estuary became weak, the river channel was stabilised and the evacuation of the riverbed was progressed, and sand and mud deposited by ebb and tide flow after heavy rains occurred in the upper part.

In the Shio River, the perennial salt mash plant community of Phragmites australis occupied over $80.0 \%$ of the area. In the Harai River, the perennial salt mash plant community of Phragmites australis occupied $65.5 \%$ of the area, and Phacelurus latifolius occupied 11.0\% (Figure 3). The basin areas of the Shio River and the Harai River were small at $50 \mathrm{~km}^{2}$ or less, and the water level change was small and stable. The average water level in the Harai River was higher during the growth period (Figure 5); however, we considered that an open weir gate and head works for irrigation use affected the water level. For the river-crossing structures, the waterfall works of the Shio River were at 16 sites on the main river and 21 sites on the branch. The Harai River was a branch that flowed into the Kushida River, and weir-head works were at the confluence with the Kushida River.

We considered that the Shio River was low in catchment after heavy rain and was a stable river environment because the waterfall works suppressed the soil supply and flow from upper areas, which allowed perennial salt marsh plants such as a Phragmites australis to grow in a stable river environment and occupy a wide range. In contrast, the Harai River contained concrete revetment and sheet piles along the river channel. In locations that were subjected to tidal flow inside and outside of these structures, Phragmites australis, Artemisia fukudo, and Carex scabrifolia were distributed, whereas Phacelurus latifolius and the upland plant community were distributed outside of those structures, which did not flood during most high tides. Perennial plants that grow in stable environments occupied a wide range.

On the basis of these results, with regard to the relationship between vegetation and river environment in each study site, we considered that when the river basin was large in scale and with few river-crossing structures, river water catchment in the estuary after heavy rains in the upper area caused large-scale disturbances that formed bare land and led to the formation of an annual salt marsh plant community. However, in conditions with many river-crossing structures, a stable channel and a river bed excavated by the suppression of catchment and the disturbance of the estuary, the location was higher and was not flooded during high tide, and vegetation such as upland plants exhibited a wide distribution. In contrast, we considered that in rivers with small basin areas and many river-crossing structures, disturbance to the estuary was not likely to occur and the perennial salt marsh plants communities of Phragmites australis and related species would be widely distributed, except for the river type with its tidal and river flow managed by a final closure, as in the Shinbori River. However, this research is the result of a limited area. In the future, moreover, it is necessary to reaffirm the results of this time on to examine the rivers and environmental characteristics that targeted wide area.

\section{Conclusions}

We examined the influences of the differences in basin scale and river-crossing structures of 8 rivers of Ise Bay in Mie and Aichi Prefectures, Japan on the vegetation in the estuarine tidal flats of these rivers.

In rivers with large basin areas and few river-crossing structures, as in the Miya River, we considered that river water catchment in the estuary after heavy rains in the upper area caused large-scale disturbances that formed bare land and led to the formation of an annual salt marsh plant community. However, in case of conditions with many river-crossing structures, a stable channel and a river bed excavated by the suppression of catchment and the disturbance of the estuary, the location was higher and was not flooded during high tide, and vegetation such as upland plants exhibited a wide distribution. 
In rivers with small basin areas and many river-crossing structures, we considered that disturbance to the estuary was not likely to occur and the perennial salt marsh plants communities of Phragmites australis and related species would be widely distributed.

On the other hand, in the river type with its tidal and river flow managed by a final closure, as in the Shinbori River. The sediment supply was suppressed from upstream by the final closure sluice. However, when tidal flow during high tide occurs below the final closure sluice, riverbed soil is disturbed by the sedimentation and erosion; therefore, the annual salt marsh plant community formed there.

\section{Acknowledgements}

This research was supported by JSPS KAKENHI Grant Number 24310025 (studies on assessment of ecosystem functions of wetlands using environmental radioisotopes).

\section{References}

[1] Nishihara, T. (1997) As for Recent Movement of "Reproduction Project of Sea in Japan”-The Action Plan Was Settled on in the Ise Bay and the Hiroshima Bay. Japanese Journal of Coastal Zone Studies, 19, 3-5.

[2] Ministry of the Environment Government of Japan (2007) Revision, List of Threatened Wildlife of Japan. Wildlife Division, Nature Conservation Bureau, Ministry of the Environment, Japan.

[3] Department of the Environment Aichi Prefectural Government (2009) Threatened Wildlife of Aichi Prefecture, RED DETA BOOK AICHI 2009. Plants, Aichi Prefecture, Japan.

[4] Mie Prefecture, Environmental Conservation Agency (2005) Threatened Wildlife of Mie 2005. Plants Mushroom, Mie Prefecture, Japan.

[5] Kaneko, K., Yabe, T. and Nohara, S. (2005) Vegetation Changes and Topographic Feature in the Delta of Obitsu River in Tokyo Bay. Japanese Journal of Landscape Ecology, 9, 27-32. http://dx.doi.org/10.5738/jale.9.2_27

[6] Kobayashi, S. (1996) The State Environment of Salt Marsh Plant Community in the Estuary-River Course Characteristics and Salinity Concentration Environment. Research Report of Ehime Prefectural Science Museum JAPAN, 1, 35-44.

[7] Kamata, M. and Ogura, Y. (2006) Habitat Evaluation for Plant Communities as a Salt Marsh in the Naka River, Shikoku Japan. Ecology and Civil Engineering, 8, 245-261. http://dx.doi.org/10.3825/ece.8.245

[8] Kaneko, K. and Nohara, S. (2013) Vegetation Communities in Estuarine Tidal Flats in the Different River and Basin Environments of the Four Major Rivers of Ise Bay (Suzuka, Tanaka, Kushida), Mie Prefecture, Japan. Open Journal of Ecology, 3, 205-213. http://dx.doi.org/10.4236/oje.2013.32024

[9] Kaneko, K. and Nohara, S. (2014) The Influence of Changes in the Degree and Frequency of Disturbance on the Annual Salt Marsh Plant (Suaeda maritima, Artemisia fukudo) Communities in Estuarine Tidal Flats: A Case Study of the Kushida River in Mie Prefecture, Japan. Open Journal of Ecology, 4, 1-10. http://dx.doi.org/10.4236/oje.2014.41001

[10] Kikuchi, E. and Kurihara, Y. (1988) Tide River. In: Kurihara, Y., Ed., Estuarine and Coastal Area of Ecology and Eco-Technology, Tokai University Press, Tokyo, 150-160.

[11] Delaune, R., Patrick, W. and Buresh, R. (1978) Sedimentation Rates Determined by 137 Cs Dating in a Rapidly Accreting Salt Marsh. Nature, 275, 532-533. http://dx.doi.org/10.1038/275532a0

[12] Deleeuw, J., Demunck, W., Olff, H. and Bakker, J. (1993) Does Zonation Reflect the Succession of Salt Marsh Vegetation-A Comparison of an Estuarine and a Coastal Island Marsh in the Netherlands. Acta Botanica Neerlandica, 42, 435-445. http://dx.doi.org/10.1111/j.1438-8677.1993.tb00719.x

[13] Dijkema, K.S. (1997) The Influence of Salt Marsh Vegetation on Sedimentation. In: Eisma, D., Ed., Intertidal Deposits River Mouths, Tidal Flats and Coastal Lagoons, CRC Press, Boca Ration, 403-414.

[14] Hatton, R.S., Delaune, R.D. and Patrick, W.H.J. (1983) Sedimentation, Accretion, and Subsidence in Marshes of Barataria Basin, Louisiana. Limnology and Oceanography, 28, 494-502. http://dx.doi.org/10.4319/lo.1983.28.3.0494

[15] Water Information System in Ministry of Land, Infrastructure, Transport and Tourism, Japan. http://www1.river.go.jp/

[16] Miyawaki, A., Okuda, S. and Suzuki, N. (1975) Vegetation in der Umgebung der Bucht von Tokyo. Institution for Transport Policy Studies, Tokyo.

[17] Kusanagi, T. (1986) Diagnosis of Primary Colour Weed. Rural Culture Association, Tokyo.

[18] Shimizu, T., Ed. (2003) Naturalized Plants of Japan. HEIBONSHA, Tokyo.

[19] Huiskes, A.H.L., Koutstaal, B.P., Herman, P.M.J., Beeftink, W.G., Markusse, M.M. and Munck, W.D.E. (1995) Seed 
Dispersal of Halophytes in Tidal Salt Marshes. Journal of Ecology, 83, 559-567. http://dx.doi.org/10.2307/2261624

[20] Hutchings, M.J. and Russel, P.J. (1989) The Seed Regeneration Dynamics of an Emergent Salt Marsh. Journal of Ecology, 77, 615-637. http://dx.doi.org/10.2307/2260974

[21] Kitamura, S. (1942) Ecology of Artemisia fukudo. Acta Phytotaxonomica et Geobotanica, 11, 59-60.

[22] Kitamura, S., Murata, G. and Hori, M. (1963) Colored Illustrations of Herbaceous Plants of Japan Vol. 1 (Sympetalae). Reserved Edition, Hoikusha Publishing, Co., Ltd., Osaka.

[23] Makino, T. (1996) Revised Makino’s Illustrated Flora in Color. In: Ono, M., Ooba, H., Nishida, M. and Murata, J., Eds., Gamopetalae, Hokuryukan Publishing, Co., Ltd., Tokyo.

[24] Ichikawa, S. and Kachi, N. (2000) Differential Salt Tolerance of Two Artemisia Species Growing in Contrasting Coastal Habitats. Ecological Research, 15, 241-247. http://dx.doi.org/10.1046/j.1440-1703.2000.00345.X

[25] Katsuyama, H. and Shimaoka, C. (2003) Vegetation and Distribution of Phacelurus latifolius in Mie Prefecture, Japan. Annual Research Report of Mie-Prefecture Environmental Conservation Agency, 9, 35-47.

[26] Okuda, S. (1997) World Plants of Japan, Growth Environment Separately. Shogakukan Inc., Tokyo.

[27] Scott, W.R. and William, A.N. (1993) Vegetation Change on a Northeast Tidal Marsh: Interaction of Sea-Level Rise and Marsh Accretion. Ecology, 74, 96-103. 